Jurnal Bisnis dan Manajemen, Volume 19, No. 2, September 2018, p. 72-87

\title{
BARRIERS AND POSSIBILITIES OF IMPLEMENTATION OF CUSTOMER RELATIONSHIP MANAGEMENT ON SMALL AND MEDIUM ENTERPRISES BY WOMENPRENEURS
}

\author{
Heny Hendrayati ${ }^{1}$, Rahmy Karimah Syahidah ${ }^{2}$ \\ ${ }^{1}$ Universitas Pendidikan Indonesia, Indonesia \\ ${ }^{2}$ Northwestern Polytechnical University, China
}

\begin{abstract}
In Indonesia, Customer Relationship Management (CRM) is commonly used by large companies. Small Medium Enterprises (SMEs) are managed traditionally despite the growing amount of transactions. The growth of SMEs in Indonesia is not supported by CRM expertise. This study aims to analyze the implementation of CRM at the level of SMEs in the field of fashion managed by womenpreneurs in West Java. This research uses a descriptive method. The unit of analysis in this study was womenpreneurs engaged in fashion industry in West Java; 200 womenpreneurs were recruited using proportional random sampling. The results reveals that technology-based CRM is the most difficult to develop in construct. CRM by womenpreneurs does not use information technology, but it emphasizes on people and the process. Developing technology-based CRM is the best way to facilitate womenpreneurs in expanding their business.
\end{abstract}

Keywords: Customer Relationship Management, fashion, information technology-based CRM, Small and Medium Enterprises, Womenpreneur

\section{HAMBATAN DAN KEMUNGKINAN IMPLEMENTASI MANAJEMEN HUBUNGAN PELANGGAN PADA UMKM WOMENPRENEUR}

\begin{abstract}
ABSTRAK
Pemanfaatan Customer Relationship Management di Indonesia masih banyak didominasi oleh perusahaan besar. Perusahaan Usaha, Kecil dan Menengah di Indonesia banyak dikelola secara tradisional, padahal besaran jumlah transaksinya semakin besar. Pertumbuhan UKM di Indonesia tidak sebanding dengan pertumbuhan keahlian CRM. Penelitian ini bertujuan untuk menganalisis pelaksanaan CRM pada level UKM di bidang fesyen yang dikelola oleh para womenpreneur di Jawa Barat. Penelitian ini menggunakan metode deskriptif. Unit analisis dalam penelitian ini adalah womenpreneur yang bergerak dalam bidang fesyen di Jawa Barat sebanyak 200 orang yang diambil secara proportional random sampling. Hasil penelitian membalikkan bahwa teknologi berdasarkan CRM merupakan hal yang paling sulit dikembangkan. CRM yang dilakukan para womenpreneur tidak terpatok pada teknologi informasi saja, namun lebih banyak menekankan kepada orang dan prosesnya. Perkembangan teknologi berdasarkan CRM merupakan jalan terbaik untuk memfasilitasi womenpreneurs dalam memperluas bisnis mereka.
\end{abstract}

Kata-kata Kunci: Customer Relationship Management, CRM berbasis teknologi informasi, industri fesyen, Usaha Kecil dan Menengah, Womenpreneur

Korespondensi: Dr. Heny Hendrayati, S,IP.MM, Universitas Pendidikan Indonesia. Jln. Setiabudhi No. 229, Isola, Sukasari, Isola, Sukasari, Kota Bandung, Jawa Barat 40154. Email: henyhendrayati@upi.edu 
Jurnal Bisnis dan Manajemen, Volume 19, No. 2, September 2018, p. 72-87

\section{INTRODUCTION}

Small, and Medium Enterprises (SMEs) have a very important role in the Indonesian economy. Based on data from the Central Bureau of Statistics (BPS) in 2014, the proportion of MSMEs in Indonesia is amounted to $99.9 \%$ or 57.9 million of the total entrepreneurs in Indonesia. The contribution of SMEs to Gross Domestic Product (GDP) is $57.93 \%$ from the total 2014 GDP of IDR 10.4 trillion. In addition, $97.30 \%$ of employment opportunities are provided by SMEs. The involvement of women in the business world, especially SMEs, is quite significant. International Finance Corporation (IFC) reported that females who lead SMEs are strong contributors to economic growth and employment, and women running SMEs in Indonesia account for nearly half of the market (IFC, 2016). The involvement of women in the business world, especially small-medium enterprises, is quite significant. From the 57.9 million SMEs business actors in Indonesia, $60 \%$ are women (BPS, 2014). This shows the important role of women in improving the Indonesian economy. The role of women in economic activities does not only strengthen the resilience of family economy (Sunyoto Usman, 2004; Haryanto, 2008; Eli, 2012), but also absorbs labor, reduces unemployment, reduces poverty and has the ability to realize a sustainable economy (Listyani \& Kharisma, 2016; Indiworo, 2017).
The paradigm of modern business approach is to pay attention to customer factors. Customers are considered important not only at the time before the transaction, but also after the transaction. Customers need to maintain their existence in order for them to be loyal and re-buy (Reichheld \& Sasser, 1990; Jones \& Sasser, 1995; Reichheld F. , 1996; Rauyruen \& Miller, 2007; and Doma, 2013). The tool from the field of information technology is called Customer Relationship Management (CRM). Currently, CRM is still predominantly used by large companies while not many SMEs employ CRM. Generally, SMEs in Indonesia are managed traditionally despite the great number of transactions. This will necessarily cause some incompatibilities when the SMEs use CRM (Rosalina, Malik, \& Perwitasari, 2017).

Marketing performance is influenced by the implementation of CRM program for maintaining customers to remain loyal. The positive influence of CRM on marketing performance results indicates that CRM affects marketing performance (Soliman, 2011; Namjoyan, Esfahani, \& Haery, 2013; Sorayaei, Reaz Valiollahi, Hossein Zadeh, Hossein Ghoryshian, \& Masoud Dinari, 2014).

Studies that examine the involvement of womenpreneurs in managing SMEs are still very rare. Over the past 20 years, according to Sciencedirect, there are only 38 studies dealing with womenpreneurs. In springerjournal.com, from 2014 to 2017 , there are only 11 research 
Jurnal Bisnis dan Manajemen, Volume 19, No. 2, September 2018, p. 72-87

articles. There has been not much research on womenpreneur in the Indonesian setting. According to Sciencedirect.com, there are only 7 studies in the past 20 years. CRM is generally implemented in large companies (Rosalina, Malik, \& Perwitasari, 2017), and research on the implementation of CRM in SMEs is still very rare.

This study aims to analyze the implementation of CRM at the SME level, especially in the field of fashion managed by womenpreneurs in West Java.

\section{LITERATURE REVIEW}

Webb, Webster, Frederick, and Jr. (2002, pp. 97-134) argue that there is a paradigm shift from the marketing of a transaction to the focus of a relationship. Basically, customer relationship management is a philosophy in doing business, a strategic orientation centered on the maintenance and upgrading of existing customers, rather than acquiring new customers.

Based on the theory of Relationship Marketing (RM), the concept of Customer relationship management is based on the premise that developing relationships with customers is the best way to retain them and to generate loyalty, and that loyal customers are more profitable than unfaithful customers (Zeithaml V. B., 2006). Customer relationship management (Buttle, 2007) is a different concept in the view of different parties. The term customer relationship management is popular in recent years among the companies engaged in Information Technology. The term Customer relationship management is used to describe various functions of marketing, sales, and service.

SME and CRM initiatives, regardless of the differences between SMEs and large companies, the implementation of CRM in SMEs cannot be regarded as a larger version of miniature organizations (Alshawi, Missi, \& Irani, 2011). SMEs have several characteristics, such as lack of resources: resources as budget (Monteiro, Marques, \& Pedron, 2012); expertise specialists (e.g. marketing; Gilmore, Carson, \& Grant, 2001; Harrigan, Ramsey, \& Ibbotson, 2012); information and communication technology (Özgener \& İraz, 2006); owner-manager dominance: the owner manager makes most of his own decisions (Özgener \& İraz, 2006; Wahlberg, Strandberg, Sundberg, \& Sand, 2009); customized products and services: capacity to customize products and services and personalize customer-specific services (Harrigan, Ramsey, \& Ibbotson, 2012; Payne \& Frow, 2005); lack of planning: since organizational management has to perform many simultaneous functions, in which they do not have time to focus on strategic planning (Monteiro, Marques, \& Pedron, 2012); flexible structure: SMEs have simple "cohesive organizational and cultural structures" and the hierarchical structures are simple and informal (Appiah-Adu \& Singh, 1998). 
Jurnal Bisnis dan Manajemen, Volume 19, No. 2, September 2018, p. 72-87

Small and medium enterprises are vital components of Indonesian economy. Thus, how they compete in today's economy is very important, and deserve greater academic attention than is currently done (e.g. Connelly, Ireland, Reutzel, \& Coom, 2010; Gilman \& Edwards, 2008; Doole, Grimes, \& Demack., 2006; O’Dwyer, Gilmore, \& Carson, 2009); lack of financial resources which limits the ability to grow (Doern R, 2009; Xu, Rohatgi, \& Duan., 2007; Wang \& Yao., 2002). In addition, SMEs tend to lack management and marketing skills (Carson, Cromie, McGowan, \& Hill, 1995; O’Dwyer, Gilmore, \& Carson, 2009). Finally, SMEs tend to be particularly vulnerable to environmental changes where their external influences are limited (Carson, Cromie, McGowan, \& Hill, 1995; Jocumsen G., 2004; Kocak \& Abimbola, 2009). These characteristics clearly impact the ability of SMEs in marketing (Doern R, 2009). This paper suggests that the kind of network marketing conducted by SMEs through intrinsic customer orientation is similar to CRM theory (Keskin, 2006; Lamprinopoulou \& Tregear, 2009; Slotte-Kock \& Coviello, 2010).

SMEs' proximity to customers can give them a unique competitive advantage compared to competitors of marketing theory that make it relevant to the way they do big and small businesses (Jack, Moult, Anderson, \& Dodd, 2010; Moreno \& Casillas, 2008; O’Dwyer, Gilmore, \& Carson, 2009; Zontanos \&
Anderson, 2004). Marketing in SMEs is an adaptation (Carson \& Gilmore, 2000). focus on simple and workable approaches that are affordable and efficient and most importantly, in line with their unique strategies and cultures (O’Dwyer, Gilmore, \& Carson, 2009). SMEs use the advantage of being small, which includes loyalty among employees, proximity to customers, flexibility to market needs, focus on opportunities, and easy access to market information (Carson, Cromie, McGowan, \& Hill, 1995; Hills, Hultman, \& Mil, 2008; O’Dwyer, Gilmore, \& Carson, 2009). In particular, SMEs do have a tendency to form closer personal relationships with customers than larger organizations (Carson, Cromie, McGowan, \& Hill, 1995; Jack, Moult, Anderson, \& Dodd, 2010; Moriarty, Jones, Rowley, \& Kupiec-Teahan, 2009). Although most SME owners are not familiar with the term CRM, this is likely to occur. This approach tends to be close to intuitive in doing business they rely on (Peltier, Schibrowsky, \& Zhao, 2009; Zontanos \& Anderson, 2004).

SMEs tend not to buy complex software packages to support CRM activities. They prefer to rely on relatively simple technologies such as websites, e-mail, and some data mining (Peltier, Schibrowsky, \& Zhao, 2009). However, it is very likely that the software package does not fit the unique and small needs of SMEs (Schoder \& Madeja, 2004). In conclusion, many SMEs do not characterize 
Jurnal Bisnis dan Manajemen, Volume 19, No. 2, September 2018, p. 72-87

everyday needs, consumer-oriented as CRM, but the reality is that this activity is very much reflective of many traits as per CRM theory. Thus, there may be a significant opportunity for SMEs to integrate internet-based technologies (IBTs) into their CRM processes. Therefore, the output is e-CRM based on the understanding that electronic-CRM (e-CRM) represents customer relationship management with the use of IBT (Yeh-Yun Lin \& Yi-Ching Chen, 2007; Ortega, Martí'nez, \& De Hoyos, 2008).

Although marketing in SMEs is similar to CRM theory (Peltier, Schibrowsky, \& Zhao, 2009; Street \& Cameron, 2007; Zontanos \& Anderson, 2004), CRM terminology is still considered unfamiliar by most SME owners or managers. They do not use complex software or commit to strategic initiatives (Peltier, Schibrowsky, \& Zhao, 2009; Wilson, Daniel, \& Davies, 2008; Zontanos \& Anderson, 2004). The reality is that owner-managers often 'do' CRM intuitively. Previous research has confirmed that the marketing of truly effective relationships cannot exist without the use of IBT (Ab Hamid \& Kassim, 2004; Yeh-Yun Lin \& Yi-Ching Chen, 2007; Zineldin, 2000). SMEs, by using technologies such as websites, e-mail, and databases to build on enable traditional CRM, can improve their inherent marketing orientation and customer focus (Dibrell, Davis, \& Craig, 2008; Harrigan, Ramsey, \& Ibbotson, 2012; Simmons,
Armstrong, \& Durkin, 2008). Literature suggests that e-CRM can generate a range of benefits for larger organizations, such as improved customer service, customer upgrades, loyalty, personalized improvement (Tan, Yen, \& Fang, 2002), and market awareness (Boulding, Staelin, Ehret, \& Johnston, 2005); Jayachandran, Sharma, Kaufman, \& Raman, 2005), creation of cost savings in marketing, sales (Letaifa \& Perrien, 2007; Patel \& Conklin, 2009) and increase of overall profitability (Reichheld \& Sasser, 1990; Reinartz, Krafft, \& Hoyer, 2004; Storbacka, Strandvik, \& Grönroos, 1994). E-CRM can also help SMEs compete more effectively in international markets (Bhatnagar, 2008; Mathews \& Healy, 2008; Ritchie \& Brindley, 2005).

However, there are some challenges for SMEs that try to integrate IBT into traditional CRM activities. The first and foremost is the potential risk for treating personally and cautiously relationships with customers (Gummesson, 2002; Jack et al., 2010; Kumar \& Reinartz, 2006; Piccoli \& Ives, 2005). Another challenge is the level of strategic thinking and direction required by the owner-managers. Previous research has shown similar initiatives to be a short-term tactical project, not a longterm integrated strategy (Hills et al., 2008; Piercy, 2009; Quader, 2007). Other challenges include lack of clarity of financial resources and marketing and technology expertise among 
Jurnal Bisnis dan Manajemen, Volume 19, No. 2, September 2018, p. 72-87

SME owners (Admiraal \& Lockhorst, 2009: Blili \& Raymond, 1993): (Street \& Meister, 2004). SMEs and customers may also lack of trust in electronic channels, where customers are cautious in disclosing personal and financial details electronically (Cavusoglu, Mishra, \& Raghunathan, 2002; Tagleyvini, Ravarini, \& Antonelli, 2001).

In SMEs, the top management, who is the owner or manager, plays an important role in business and decision making (Bruque \& Moyano, 2007; Denison et al., 2004). Studies have been undertaken to investigate social behavior and terms of reference for management in relation to IT. The studies show that the greater their understanding of IT, the more likely they will adopt IT and the more successful the technology adoption (Chao \& Chandra, 2012; Cooper et al., 2005; DeLone, 1988; Pansiri \& Temtime, 2010). Management Innovation is also Linked to Receive New IT Research conducted by Thong and Yap (1995) which shows that Managers who are very innovative and have a positive attitude towards IT along with competent IT background are more likely to succeed in adopting new IT (see CRM Technology Articles in new folders). Therefore, it can be concluded that the owners of SMEs who understand IT will be able to adopt IT CRM.

According to Fazlzadeh, Tabrizi, \& Mahboobi (2011), there are four factors identified as the main dimensions underlying
CRM in SMEs in Eastern Azerbaijan in Iran. The factors are (1) infrastructure distribution of communication; (2) business dynamics; customer relationship; and (4) innovation and quality.

For SMEs, there may be two main areas of e-CRM implementation in SMEs, customer communication and customer information management (Hart, Ozdemir, \& Tagg, 2009; O'Cass \& Weerawardena, 2009; O’Dwyer, Gilmore, \& Carson, 2009). Communication with customers in SMEs tends to be constant, informal and open, with the goal of creating shared values (Gilmore, Gallagher, \& Henry, 2007; Street \& Cameron, 2007). There is also a tendency that the social aspect of this relationship is in the form of face-to-face contact (Gilmore, Gallagher, \& Henry, 2007; Ritchie \& Brindley, 2005). However, IBTs such as e-mail and websites can facilitate theinteractions, improve efficiency, enable personalization, and save face-to-face time for important issues (Nambisan \& Baron, 2007; Ortega et al., 2008; Simmons, Armstrong, and Durkin, 2008). Thus, to meet the needs of customers effectively and efficiently, SMEs should maintain a level of communication with customers. They should also be able to obtain and manage information about their customers (Westhead, Ucbasaran, \& Wright, 2009). The information is invaluable in marketing decision making, particularly in the recording of customers' personal details, unique 
Jurnal Bisnis dan Manajemen, Volume 19, No. 2, September 2018, p. 72-87

requirements, historical orders, value for the company, and the future projection of orders (Chan, 2005; Coltman, 2007; Keh, Nguyen, and Ng, 2007; Rai, Patnayakuni, and Seth, 2006). It also helps SMEs in their market segmentation. Unlike large organizations, SMEs do not have the resources to engage in formal market research. So, their relationships with customers which they maintain are a major source of valuable information (Hutchinson \& Quintas, 2008; Keh, Nguyen, and Ng, 2007). Therefore, CRM in SMEs should consist of acquisition, management, analysis, and utilization of information (Im \& Workman, 2004; Keh, Nguyen, \& Ng, 2007). The IBT 'back office' such as websites and databases of customer information management play important roles in assisting the administration, storage, and processing of customer data for SMEs. It is possible to personalize products and service offerings to specific customers, treat the most valued customers differently and better in predicting customer behavior (e.g. Hutchinson \& Quintas, 2008; Parvatiyar \& Sheth, 2001; Ryals \& Knox, 2001).

In Lin, Chen, R, and Chiu, K (2010), emphasized by Colaco (2015), there are four major dimensions for analyzing customer relationship management activities. These dimensions are based on the interactions between organizations and their customers. The dimensions are (1) information sharing that happens in the sharing of information and knowledge between organizations and customers as a result of market demand, consumer preferences, and new products (Lin, Chen, R, \& Chiu, K, 2010); (2) customer involvement that involves contributions or feedback from customers about new products and services since customers often provide better knowledge of current demand and future demands by looking at market trends (Lin, Chen, R, \& Chiu, K, 2010); (3) long-term relationship that concerns about important factors in the market, trust and commitment between the organization and the customers considering that partnership is a business relationship between two or more partners who share the same benefits of the relationship (Lin, Chen, R, \& Chiu, K, 2010); (4) technologybased CRM (technology-based customer relationship management) which covers how an organization uses technology to enhance CRM activities and has technology support for customers, such as CRM software systems. (Lin, Chen, R, \& Chiu, K, 2010). Because SMEs have low capital and liquidity limitations, they need low-cost CRM applications that can be tailored to their business models and infrastructure. The alternative, changing their business model and IT structure to fit the CRM application, is not popular. In addition, preference is expressed in introducing new Software to be done in small steps, not to interrupt current business processes. This is in accordance with the 
Jurnal Bisnis dan Manajemen, Volume 19, No. 2, September 2018, p. 72-87

suggestion that business processes are gradually adapted to future environmental changes, as well as software adaptable to the future of this change (Baumeister, 2002).

\section{METHODS}

The object studied in this research is CRM. The target of this research is womanpreneurs who manage fashion SMEs in West Java. To obtain a representative sample size, various sample calculation techniques were performed. Considering the micro, small and medium industries that are the analysis units spread in 27 districts/ cities, the sampling technique used is random sampling. In this study, proportional randomization was conducted to each city/district in West Java. The study involved 200 respondents taken based on proportional random sampling.

Data collection was carried out through (1) in-depth interviews with several womenpreneurs in West Java, West Java Industry and Trade Agency, IWAPI Jabar, Creative Economy Agency on issues related to CRM, (2) questionnaire, distributed to the respondents, (3) literature study, carried out by reviewing and reviewing journals, books, other references, notes/reports and other documents from various institutions that are related to the problem under study.

\section{RESULTS AND DISCUSSION}

Customer relationship management variable can be measured through sub-variables of information sharing, customer involvement, long-term relationship, and technology-based customer relationship management (CRM).

Table 1 Customer Relationship Management

\begin{tabular}{ccccc}
\hline No & \multicolumn{1}{c}{ Dimension } & Scores & $\begin{array}{c}\text { Ideal } \\
\text { Scores }\end{array}$ & $\%$ \\
\hline 1 & $\begin{array}{l}\text { Information Sharing } \\
\text { Customer }\end{array}$ & 2509 & 3000 & $84 \%$ \\
2 & $\begin{array}{l}\text { Involvement } \\
\text { Long term } \\
\text { relationship } \\
4\end{array}$ & 5712 & 7000 & $78 \%$ \\
& $\begin{array}{l}\text { Techonolgy based } \\
\text { CRM }\end{array}$ & 785 & 1000 & $79 \%$ \\
\multicolumn{1}{c}{ Total } & 10348 & 14000 & $81 \%$ \\
\hline Source: Data Processing Results (2017) & & \\
\end{tabular}

Table 1 shows that, from these four indicators, information sharing is the highest rated indicator with a score of $84 \%$. By sharing information with customers, it is expected that a company can create products that match the customers' demand. Not just sharing product information alone, companies try to share inventory and promotional information. It is a company's efforts to produce right-on-target products. The lowest rated dimension is customer involvement with a score of $78 \%$.

In general, micro, small, to medium enterprises have very sensitive to positive perceptions of existing customers about the business offered. SMEs do not really have the resources to aggressively market their products and services in order to attract new customers. In such conditions, retaining existing customers is very important. One way which can be done by the womenpreneurs in West Java is by conducting Customer Relationship Management program. 
Jurnal Bisnis dan Manajemen, Volume 19, No. 2, September 2018, p. 72-87

Customer Relationship Management conducted by womenpreneurs in West Java is high. This means that womenpreneurs in West Java, despite their position in the level of SMEs, mostly have been able to apply the concept of CRM. CRM is not necessarily related to technology. On a micro and small scale, people often wonder how CRM is implemented. In fact, CRM is not only owned by medium and large companies. So far, according to the womenpreneurs, in micro and small scale they have actually implemented the concept of CRM informally. For example, they friendly greet every customer and respond to every inquiry from customers. These are simple forms of CRM. The relationship of womenpreneurs and customers in business is very close because the relationship mostly occurs face to face, intense, and informal.

Information sharing and long-term partnership are the most dominant efforts done by womenpreneurs in West Java in this CRM activity. Information sharing activities aim to share important information about new product offerings, new stocks, and discounts for customers. Although customer involvement and technology-based CRM are in the high category, they are still done in a simple method by the womenpreneurs in West Java. In terms of consumer involvement in the production process, they are not yet at the stage of cocreation. However, they listen to suggestions and feedback from consumers about products that consumers want. Similarly, the utilization of technology is still simple, but they take full advantage of the internet to create a database and maintain their customers in terms of promotion and other information. Information technology that is widely used includes Instagram, Facebook, Whats App, and Blac BM.

Based on the results of interviews, on the scale of micro and small enterprises, CRM conducted by womenpreneur in West Java has the following characteristics. (1) The implementation of CRM is simple because the needs are still simple. The transaction process conducted by SMEs is also still simple, (2) The relationship between womenpreneurs and customers is close and considered as personal, (3) The womenpreneurs have not had a good system, such as data-based CRM and information technology on large-scale enterprises. CRM in MSME only covers communication and information to answer the needs of consumers, (4) There is no online database or information technology, MSMEs still use manual database and traditional business. For example, they use paper/books to record purchase and sales of goods, (6) Although womenpreneurs have not been able to use technology like in big companies, basically they have implemented the concept of CRM in simple ways. They communicate with customers through mobile telecommunication equipment (e.g. via SMS, Whatsapp, BBM, social media -like Facebook 
Jurnal Bisnis dan Manajemen, Volume 19, No. 2, September 2018, p. 72-87

and Instagram) because they are cheap and do not need big investments, (7) Most of SMEs managed by womenpreneurs use simple network infrastructures because they do not use distributed databases. This means that the network is not a complicated network like in large companies, but only utilizes a simple customer database system by creating BBM Group or Whatsapp Group which serves as a forum for sharing product information and promotion, (8) The risk tends to be low because customer data are obtained through information technology that is not too complicated and managed using a database without being distributed, (9) Womenpreneurs do not have sufficient funds to hire skilled information technology specialists so that CRM applications do not require specialized informatics engineering skills, (10) MSMEs managed by womenpreneurs have a relatively stable business tendency. It is not very dynamic. So, it requires CRM that can be implemented without having to make changes to the business process. Simple data mining is required to handle the behavior of its customers, (11) CRM widely used by womenpreneurs is by connecting within a particular community, becoming a member or part of groups or communities. Therefore, the socialite-womenpreneurs will influence marketing performance, (12) Relationships maintained with CRM are not only with product customers but also with all stakeholders such as suppliers and governments.

Based on the interviews, it can be seen that CRM by womenpreneurs are not dependent on information technology, but more on people and process. This is in line with the opinions of experts who claim that although the advancement of information technology in recent years plays an important role in the evolution of CRM, it is important to emphasize that CRM is not just about technology (Johnson, 2004); (Light, 2003); (Selland, \& Pockard, 2003); (Zablah, Bellenger and Johnston, 2004). In contrast, CRM is a complex concept that combines business and technological factors (Bull, 2003). In particular, technology is a tool that enables organizations to gain a better understanding of their customers, which will increase their ability to build long-term relationships and improve customer retention (Chen and Popvich, 2003); (Little and Marandi, 2003); (Puccinelli, 1999). This argument is supported by the literature (Bull, 2003); (Croteau and Li, 2003); (Nancarrow et al., 2003); (Stefanou et al., 2003); (Wall, Akridge, and Wang, 2004). For example, according to Bradshaw and Brash (2001), “... while implementing CRM inevitably involves the adoption of new technologies, it needs a reexamination of business processes, which should lead technology decisions, and not vice versa". In addition, Chen and Popvich (2003) also 
Jurnal Bisnis dan Manajemen, Volume 19, No. 2, September 2018, p. 72-87

mentioned that “... seeing CRM as a technology-only solution is likely to fail. Managing a successful CRM implementation requires an integrated and balanced approach to technology, processes and people." Feinberg, Kadam, Hokama, and Kim (2002) also argue, “... not just technology, data mining, or call center". Seeing the above statements, it is suggested that CRM is not just technology.

The application of CRM to fashion SMEs in West Java can be said to have started running both in terms of people, processes, and technology. This aligns with the view of Beldi, Cheffi, and Dey (2010), that CRM is an integration of technology, people, and business processes used to meet customer needs, and to enhance interaction with clients.

\section{CONCLUSION}

In terms of the application of CRM conducted by womenpreneurs, SMEs in the field of fashion in West Java are in the high category. From the four dimensions of CRM, the dimension of customer involvement is still rarely implemented by the SMEs.

\section{ACKNOWLEDGEMENTS}

We would like to express our deepest gratitude to Ministry of Research, Technology, and Higher Education of Indonesia for the Research Grant "Penelitian Unggulan Perguruan Tinggi 2018" and also to Universitas Pendidikan Indonesia, who have facilitated and helped the research from the beginning till its completion.

\section{REFERENCES}

Ab Hamid, N., \& Kassim, N. (2004). Internet technology as a tool in customer relationship management. Journal of American Academy of Business, 4(1/2), 103-8.

Admiraal, W., \& Lockhorst, D. (2009). E-Learning in small and medium-sized enterprises across Europe attitudes towards technology, learning and training. International Small Business Journal, 27(6), 743-767.

Alshawi, S., Missi, F., \& Irani, Z. (2011). Organisational, Technical and Data Quality Factors in CRM Adoption - SMEs Perspective. Industrial Marketing Management, 40(3), 376383.

Appiah-Adu, K., \& Singh, S. (1998). Customer orientation and performance: a study of SMEs. Management decision, 36(6), 385-394.

Baumeister , H. (2002). Customer relationship management for SME's. LMU oettingenstr. 67, D-80538 Munchen, Germany, pp. 1-7: Institut fur Informatik.

Beldi, A., Cheffi, W., \& Dey, P. (2010). Managing customer relationship management projects: The case of a large French telecommunications company. International Journal of Project Management, 28(4), 339-351.

Bhatnagar, A. (2008). Product choice for international web-based SMEs. International Journal of Internet Marketing and Advertising, 4(2-3), 145-155.

Blili, S., \& Raymond, L. (1993). Information technology: Threats and opportunities for small and medium-sized enterprises. International journal of information management, 13(6), 439-448.

Boulding, W., Staelin, R., Ehret, M., \& Johnston, W. (2005). A customer relationship management roadmap: What is known, potential pitfalls, and where to go. Journal of marketing, 69(4), 155-166.

BPS, 2014. (2014). BPS. Indonesia: www. bps.go.id.

Bradshaw, D., \& Brash, C. (2001). Managing customer relationships in the e-business world: how to personalise computer relationships for increased profitability. International Journal of Retail \& Distribution Management, 29(12), 520-530.

Bruque, S., \& Moyano, J. (2007). Organisational determinants of information technology adoption and implementation in SMEs: The case of family and cooperative firms. Technovation, 27(5), 241-253. 
Jurnal Bisnis dan Manajemen, Volume 19, No. 2, September 2018, p. 72-87

Bull, C. (2003). Strategic issues in customer relationship management (CRM) implementation. Business process management Journal, 9(5), 592-602.

Buttle, F. (2007). Customer Relationship Management (Manajemen Hubungan Pelanggan) : Concept and Tools. Malang: Bayumedia Publishing.

Carson, D., \& Gilmore, A. (2000). SME marketing management competencies. International Business Review, 9(3), 363-382.

Carson, D., Cromie, S., McGowan, P., \& Hill, J. (1995). Marketing and entrepreneurship in SMEs: An innovative approach. London: Prentice Hall.

Cavusoglu, H., Raghunathan, S., \& Mishra, B. (2002). Optimal design of information technology security architecture. ICIS 2002 Proceedings, 74.

Chan, J. (2005). Toward a unified view of customer relationship management. Journal of American Academy of Business, 6(1), 32-38.

Chao, C., \& Chandra, A. (2012). Impact of owner's knowledge of information technology (IT) on strategic alignment and IT adoption in US small firms. Journal of Small Business and Enterprise Development, 19(1), 114-131.

Chen, I., \& Popovich, K. (2003). Understanding customer relationship management (CRM) People, process and technology. Business process management journal, 9(5), 672-688.

Colaco, M. M. (2015). The role of customer relationship management in organization iinovation capability. Portugal: Lisboa School of Economic \& Management.

Coltman, T. (2007). Why build a customer relationship management capability? The Journal of Strategic Information Systems, 16(3), 301-320.

Connelly, B., Ireland, R., Reutzel, C., \& Coom, J. (2010). The power and effects of entrepreneurship research. Entrepreneurship Theory and Practice, 34, 131-149.

Croteau, A., \& Li, P. (2003). Critical success factors of CRM technological initiatives. Canadian Journal of Administrative Sciences/Revue Canadienne des Sciences de l'Administration, 20(1), 21-34.

DeLone, W. (1988). Determinants of success for computer usage in small business. Mis Quarterly, 51-61.

Denison, D., Lief, C., \& Ward, J. (2004). "Culture in family-owned enterprises: recognizing and leveraging unique strengths". Family Business Review, Vol. 17 No. 1, pp. 61-71.
Dibrell, C., Davis, P., \& Craig, J. (2008). Fueling innovation through information technology in SMEs. Journal of small business management, 46(2), 203-218.

Doern, R. (2009). Investigating to SME Growth and Development in Transition Environments : A Critique and Suggestions for Developing The Methodology. International Small Business Journal, 27, 275-305.

Doma, S. (2013). Relationship quality as predictor of B2B customer loyalty. Systemics, Cybernetics And Informatics, 11(1), 72-78.

Doole, I., Grimes, T., \& Demack, S. (2006). An exploration of the management practices and processes most closely associated with high levels of export capability in SMEs. Marketing Intelligence and Planning, 24, , 632-647.

Eli, Y. (2012). Pemberdayaan Kaum Perempuan dalam Menunjang Peningkatan Pendapatan Keluarga melalui Home Industry di Dusun Pelemadu, Desa Sriharjo, Kecamatan Imogiri, Kabupaten Bantul, DIY. Doctoral dissertation, Universitas Negeri Yogyakarta.

Fazlzadeh, A., Tabrizi, M., \& Mahboobi, K. (2011). Customer relationship management in smallmedium enterprises: The case of science and technology parks of Iran. African Journal of Business Management, 5(15), 6159.

Feinberg, R., Kadam, R., Hokama, L., \& Kim, I. (2002). The state of electronic customer relationship management in retailing. International Journal of Retail \& Distribution Management, 30(10), 470-481.

Gilman , M., \& Edwards, P. (2008). Testing a framework of the organization of small firms: Fast-growth, high-tech SMEs. International Small Business Journal, 26, 531-558.

Gilmore, A., Carson, D., \& Grant, K. (2001). SME marketing in practice. Marketing intelligence \& planning, 19(1), 6-11.

Gilmore, A., Gallagher, D., \& Henry, S. (2007). Emarketing and SMEs: operational lessons for the future. European Business Review, 19(3), 234-247.

Gummesson, E. (2002). Total relationship marketing: Marketing management, relationship strategy and CRM approaches for the network economy. Total relationship marketing: marketing management, relationship strategy and CRM approaches for the network economy.

Harrigan, P., Ramsey, E., \& Ibbotson, P. (2012). Exploring and Explaining SME Marketing: Investigating E-CRM Using a Mixed Methods 
Jurnal Bisnis dan Manajemen, Volume 19, No. 2, September 2018, p. 72-87

Approach. Journal of Strategic Marketing, 20(2), 127-163.

Hart, S., Ozdemir, S., \& Tagg, S. (2009). Marketing capability, new product survival and NPD success: An exploration of relationships. In Academy of Marketing Conference, Leeds, $U K$.

Haryanto, S. (2008). Jurnal Ekonomi Pembangunan Vol. 9, No. 2, 216 - 227.

Hills, G., Hultman, C., \& Miles, M. (2008). The evolution and development of entrepreneurial marketing. Journal of Small Business Management, 46(1), 99-112.

Hutchinson, V., \& Quintas, P. (2008). Do SMEs do knowledge management? Or simply manage what they know? International Small Business Journal, 26(2), 131-154.

IFC. (2016). UKM yang dimiliki Wanita di Indonesia: Kesempatan Emas untuk Institusi Keuangan Lokal. International Finance Corporation World Bank Group, 68.

Im, S., \& Workman , J. (2004). "Market Orientation, Creativity, and New Product Performance in High-Technology Firms,". Journal of Marketing, 68 (2), 114-32.

Indiworo, H. (2017). Peran Perempuan dalam Meningkatkan Kinerja UMKM. Equilibria Pendidikan. Jurnal Ilmiah Pendidikan Ekonomi, 1(1), 40-58.

Jack, S., Moult, S., Anderson, A., \& Dodd, S. (2010). An entrepreneurial network evolving: Patterns of change. International Small Business Journal, 28(4), 315-337.

Jayachandran, S., Sharma, S., Kaufman, P., \& Raman. (2005). The role of relational information processes and technology use in customer relationship management. Journal of marketing, 69(4), 177-192.

Jocumsen, G. (2004). How do small business managers make strategic marketing decisions? A model of process. European Journal of Marketing Vol. 38, 659-674.

Johnson, J. (2004). Making CRM technology work. Manager, 22.

Jones, T., \& Sasser, E. (1995). Why satisfied customers defect. Harv Bus Rev, 88-99.

Keh, H., Nguyen, T., \& Ng, H. (2007). The effects of entrepreneurial orientation and marketing information on the performance of SMEs. Journal of business venturing, 22(4), 592-611.

Keskin, H. (2006). Market orientation learning orientation and innovation capabilities in SMEs: An extended model. European Journal of Innovation Management, 9, 396-417.
Kocak, A., \& Abimbola, T. (2009). The Effects of Entrepreneurial Marketing on Born Global Performance. International Marketing Review, 26, 439-452.

Kumar, V., \& Reinartz. (2006). Customer Relationship Management. A Databased Approach.

Lamprinopoulou, C., \& Tregear, A. (2009, July). How do SME networks evolve? Investigating network context features and outcomes.,. Paper presented at the Academy of Marketing Conference Leeds, UK.

Letaifa, S., \& Perrien, J. (2007). The Impact of ECRM on organisational and Individual behavior: the Effect of the remuneration and reward system. International Journal of EBusiness Research, 3(2), 13.

Light, B. (2003). CRM packaged software: a study of organisational experiences. Business Process Management Journal, 9(5), 603-616.

Lin, R., Chen, R, \& Chiu, K. (2010). Customer Relationship Management and Innovation Capability : an empirical study. Industrial Management \& Data System, 111-133.

Listyani, R., \& Kharisma, I. (2016). UMKM: Wujud Kemandirian Ekonomi Perempuan Menuju Perekonomian Global. Al-Adalah, 19, 1.

Little, E., \& Marandi, E. (2003). Relationship marketing management. Cengage Learning EMEA.

Mathews, S., \& Healy, M. (2008). 'From garage to global': the internet and international market growth, an SME perspective. International Journal of Internet Marketing and Advertising, 4(2-3), 179-196.

Monteiro, P., Marques, T., \& Pedron, C. (2012). Customer Relationship Management e as Pequenas e Médias Empresas: Um Estudo de Múltiplos Casos em Empresas Portuguesas. REGE - Revista de Gestão, 19(2), 341-356.

Moreno, A., \& Casillas, J. (2008). Entrepreneurial orientation and growth of SMEs: A causal model. Entrepreneurship theory and practice, 32(3), 507-528.

Moriarty, J., Jones, R., Rowley, J., \& Kupiec-Teahan, B. (2009). Executive training exercises in small hotel marketing. International Journal of Culture, Tourism and Hospitality Research, 3(4), 337-346.

Nambisan, S., \& Baron, R. (2007). Interactions in virtual customer environments: Implications for product support and customer relationship management. Journal of interactive marketing, 21(2), 42-62. 
Jurnal Bisnis dan Manajemen, Volume 19, No. 2, September 2018, p. 72-87

Namjoyan, M., Esfahani, A., \& Haery, F. (2013). Studying the effects of customer relationship management on the marketing performance (Isfahan Saderat Bank as a case study). International Journal of Academic Research in Business and Social Sciences, 3(9), 302.

Nancarrow, C., Rees, S., \& Stone, M. (2003). New directions in customer research and the issue of ownership: A marketing research viewpoint. Journal of Database Marketing \& Customer Strategy Management, 11(1), 26-39.

O'Cass, A., \& Weerawardena, J. (2009). Examining the role of international entrepreneurship, innovation and international market performance in SME internationalisation. European Journal of Marketing, 43(11/12), 1325-1348.

O'Dowyer, M., Gilmore, A., \& Carson, D. (2009). Innovative Marketing in SMEs. European Journal of Marketing, 43, 46-61.

Ortega, B., Martínez, J., \& De Hoyos, M. (2008). The role of information technology knowledge in B2B development. International Journal of EBusiness Research, 4(1), 40.

Ortega, J., \& Aguillo, I. (2008). Visualization of the Nordic academic web: Link analysis using social network tools. Information Processing \& Management, 44(4), 1624-1633.

Özgener, Ş., \& İraz, R. (2006). Customer relationship management in small-medium enterprises: The case of Turkish tourism industry. Tourism Management, 27(6), 1356-1363.

Pansiri, J., \& Temtime, Z. (2010). Linking firm and managers' characteristics to perceived critical success factors for innovative entrepreneurial support. Journal of Small Business and Enterprise Development, 17(1), 45-59.

Parvatiyar, A., \& Sheth, J. (2001). Customer relationship management: Emerging practice, process, and discipline. Journal of Economic and Social research, 3(2), 1-34.

Patel, P., \& Conklin, B. (2009). The balancing act: the role of transnational habitus and social networks in balancing transnational entrepreneurial activities. Entrepreneurship Theory and Practice, 33(5), 1045-1078.

Payne, A., \& Frow, P. (2005). A strategic framework for customer relationship management. Journal of marketing, 69(4), 167-176.

Payne, A., \& Frow, P. (2006). Customer relationship management: from strategy to implementation. Journal of Marketing Management, 22(1-2), 135-168.
Peltier, J., Schibrowsky, J., \& Zhao, Y. (2009). Understanding the antecedents to the adoption of CRM technology by small retailers: entrepreneurs vs owner-managers. International Small Business Journal, 27(3), 307-336.

Piccoli, G., \& Ives, B. (2005). IT-dependent Strategic Initiatives and Sustained Competitive Advantage. A review and synthesis of the literature, MIS Quarterly 29(4), 747-777.

Piercy, N. (2009). Strategic relationships between boundary-spanning functions: Aligning customer relationship management with supplier relationship management. Industrial Marketing Management, 38(8), 857-864.

Puccinelli, B. (1999). Bank Systems \& Technology. 36.

Quader, M. S. (2006). THE STRATEGIC IMPLICATION OF ELECTRONIC COMMERCE FOR SMALL AND MEDIUM SIZED ENTERPRISES. Journal of Services Research, 6(2).

Rai, A., Patnayakuni, R., \& Seth, N. (2006). Firm performance impacts of digitally enabled supply chain integration capabilities. MIS quarterly, 225-246.

Rauyruen , P., \& Miller, K. (2007). Relationship quality as a predictor of $\mathrm{B} 2 \mathrm{~B}$ customer loyalty. Journal of business research, 60(1), 21-31.

Reichheld , F. (1996). Learning from customer defections. Harv Bus Rev 74(2), 56.

Reichheld, F., \& Sasser, J. (1990). Zero defections: Quality comes to services. Harvard business review, 68(5), 105-111.

Reinartz, W., Krafft, M., \& Hoyer, W. (2004). The customer relationship management process: Its measurement and impact on performance. Journal of marketing research, 41(3), 293305.

Ritchie, B., \& Brindley, C. (2005). ICT adoption by SMEs: implications for relationships and management. New Technology, Work and Employment, 20(3), 205-217.

Rosalina, V., Malik, A., \& Perwitasari, E. (2017). Sosialisasi Peningnya Customer Relationship Management (CRM) Dalam Upaya Meningkatkan Retensi Pelanggan Pada Usaha Mikro Kecil Dan Menengah (UMKM) di Cilegon. Wikrama Parahita: Jurnal Pengabdian Masyarakat, 1(1), 41-44.

Ryals, L., \& Knox, S. (2001). Cross-functional issues in the implementation of relationship marketing through customer relationship 
Jurnal Bisnis dan Manajemen, Volume 19, No. 2, September 2018, p. 72-87

management. European management journal, 19(5), 534-542.

Schoder, D., \& Madeja, N. (2004). Is customer relationship management a success factor in electronic commerce? J. Electron. Commerce Res., 5(1), 38-53.

Selland, C., \& Pockard, D. (2003). Are companies responsible for their CRM failures. Network World, 20(28), 29.

Simmons, G., Armstrong, G., \& Durkin, M. (2008). A conceptualization of the determinants of small business website adoption: Setting the research agenda. International Small Business Journal, 26(3), 351-389.

Slotte-Kock, S., \& Coviello, N. (2010). Entrepreneurship research on network processes: A review and ways forward. Entrepreneurship Theory and Practice, 34, 31-57.

Soliman, H. (2011). Customer relationship management and its relationship to the marketing performance. International journal of business and social science, 2(10).

Sorayaei, A., Reaz Valiollahi, H., Hossein Zadeh, M., Hossein Ghoryshian, S., \& Masoud Dinari, A. (2014). Impact of customer relationship management (CRM) on marketing performance: A case study in Mellat bank of Mazandaran Province. European Online Journal of Natural and Social Sciences: Proceedings, 2(3 (s), pp-2612.

Stefanou, C., Sarmaniotis, C., \& Stafyla, A. (2003). CRM and customer-centric knowledge management: an empirical research. Business Process Management Journal, 9(5), 617-634.

Storbacka, K., Strandvik, T., \& Grönroos, C. (1994). Managing customer relationships for profit: the dynamics of relationship quality. International journal of service industry management, 5(5), 21-38.

Street, C., \& Cameron, A. (2007). External relationships and the small business: A review of small business alliance and network research. Journal of Small Business Management, 45(2), 239-266.

Street, C., \& Meister, D. (2004). Small business growth and internal transparency: the role of Information Systems. MIS Quarterly, 28(3), 473-506.

Tagleyvini, M., Ravarini, A., \& Antonelli, A. (2001). An evaluation model for electronic commerce activities within SMEs. Information Technology and Management, 2(2), 211-230.
Tan, X., Yen, D., \& Fang, X. (2002). Internet integrated customer relationship management a key success factor for companies in the ecommerce arena. Journal of Computer Information Systems, 42(3), 77-86.

Thong, J., \& Yap, C. (1995). CEO characteristics, organizational characteristics and information technology adoption in small businesses. Omega, 23(4), 429-442.

Usman, S. (2004). Di antara harapan dan kenyataan: esai-esai perubahan sosial. Center for Indonesian Research and Development.

Wahlberg, O., Strandberg, C., Sundberg, H., \& Sand, K. (2009). Trends, topics and under-researched areas in CRM research: a literature review. International Journal of Public Information Systems, 3, 191-208.

Wall, S., Akridge, J., \& Wang, P. (2004). Customer relationship management. Organizational elements hold the key. Agri Marketing, 42, 54.

Wang, Y., \& Yao, Y. (2002). Sources of China's economic growth 1952-1999: Incorporating human capital accumulation. China Economic Review, 116, 32-52.

Webb D, C, W., \& Frederick E, J. (2002). "Market Driven Management, 2th edition" page 97134. New Jersey: John Wiley \& Sons, Inc.

Westhead, P., Ucbasaran, D., \& Wright, M. (2009). Information search and opportunity identification the importance of prior business ownership experience. International Small Business Journal, 27(6), 659-680.

Wilson, H., Daniel, E., \& Davies, I. (2008). The diffusion of e-commerce in UK SMEs. Journal of marketing management, 24(5-6), 489-516.

Xu, M., Rohatgi, R., \& Duan, Y. (2007). E-business adoption in SMEs: Some preliminary findings from electronic components industry. International Journal of E-Business Research, 3, 74-90.

Yeh-Yun Lin, C., \& Yi-Ching Chen, M. (2007). Does innovation lead to performance? An empirical study of SMEs in Taiwan. Management Research News, 30(2), 115-132.

Zablah, A., Bellenger, D., \& Johnston, W. (2004). An evaluation of divergent perspectives on customer relationship management: Towards a common understanding of an emerging phenomenon. Industrial marketing management, 33(6), 475-489.

Zeithaml, V. B. (2006). Services Marketing: Integrating Customer Focus Across The Firm. New York: McGraw Hill. 
Jurnal Bisnis dan Manajemen, Volume 19, No. 2, September 2018, p. 72-87

Zineldin, M. (2000). Beyond relationship marketing: technologicalship marketing. Marketing Intelligence \& Planning, 18(1), 9-23.

Zontanos, G., \& Anderson, A. (2004). Relationships, marketing and small business: an exploration of links in theory and practice. Qualitative market research: an international journal, 7(3), 228-236. 